\title{
Collagenolytic Potential of Rat Liver Myofibroblasts
}

\author{
A. JIROUTOVÁ ${ }^{1}$, E. PETEROVÁ ${ }^{1}$, L. BITTNEROVÁ ${ }^{1}$, R. SLAVKOVSKÝ ${ }^{1,2}$, \\ P. ČEVELOVÁ ${ }^{1}$, M. ŘEZÁČOVÁ ${ }^{1}$, J. CERMAN ${ }^{1}$, S. MIČUDA ${ }^{3}$, J. KANTA ${ }^{1}$
}

${ }^{1}$ Department of Medical Biochemistry, Faculty of Medicine in Hradec Králové, Charles University in Prague, Hradec Králové, Czech Republic, ${ }^{2}$ Group of Cell Physiology, Contipro Biotech, Dolní Dobrouč, Czech Republic, ${ }^{3}$ Department of Pharmacology, Faculty of Medicine in Hradec Králové, Charles University in Prague, Hradec Králové, Czech Republic

Received May 30, 2012

Accepted August 31, 2012

On-line November 22, 2012

\section{Summary}

Rat liver myofibroblasts (MFB) were isolated by repeated passaging of nonparenchymal liver cell fraction. They were cultured on polystyrene Petri dishes, on fibrin or on type I collagen gels for 5 days. Quantitative RT-PCR, Western blotting, zymography and immunocytochemistry were used to study differences in cell morphology and protein expression. MFB were large and spread on plastic substrate, with prominent a-smooth muscle (a-SMA) fibres. They turned much smaller and elongated on collagen which was accompanied by the rearrangement of the cytoskeleton and a decrease in a-SMA and $\beta$-actin content. Collagen gel induced the expression of a group of metalloproteinases (MMP-2, $-3,-9,-13$ ), on mRNA and protein level which resulted in the degradation of the gel. This response was accompanied by changes in the mRNA expression of cytokines of TGF- $\beta$ family, CTGF and interleukin- 6 , as well as of osteopontin and thrombospondin-2 that are involved in metalloproteinases (MMPs) regulation. The expression of MMPs substrates, collagen types I, IV and XII did not change or decreased. The effects of fibrin gels on MFB were milder than those of collagen. MFB assumed to deposit collagen and other ECM components in fibrotic liver, besides hepatic stellate cells, also possess a great collagenolytic potential.

\section{Key words}

Liver myofibroblasts • Extracellular matrix • Cytoskeleton • Gene expression • Matrix metalloproteinases

\section{Corresponding author}

J. Kanta, Faculty of Medicine in Hradec Králové, Šimkova 870, 50038 Hradec Králové, Czech Republic. Fax: +420 495512715. E-mail: kanta@lfhk.cuni.cz

\section{Introduction}

Excessive accumulation of extracellular matrix (ECM) is a characteristic feature of liver fibrosis. Various types of myofibroblastic cells are probably responsible for this process (Guyot et al. 2006, Parola et al. 2008). Quiescent hepatic stellate cells (HSC) are activated in injured liver and change their phenotype to myofibroblast-like. HSC that store vitamin A in normal liver proliferate, become sensitive to PDGF, TGF- $\beta$ and other cytokines and begin to synthesize collagen and other ECM components (Pinzani and Gentilini 1999).

Besides HSC, also myofibroblasts (MFB) participate in the formation of connective tissue septa in fibrotic liver (Kinnman and Housset 2002). MFB differ from HSC in the expression of certain antigens and in the localization in the developing fibrotic septa (Knittel et al. 1999a). HSC can be maintained in culture for two passages while MFB allow prolonged cultivation (Knittel et al. 1999b). The fraction of quiescent HSC isolated from normal rat liver contains MFB as a minor cell type (Ogawa et al. 2007). MFB can be isolated by repeated passaging of HSC fraction of liver cells. Both activated HSC and MFB contain $\alpha$-smooth muscle actin fibers but MFB are desminnegative. The expression of the genes coding for the proteins related to connective tissue metabolism is also different in these two cell types (Jiroutova et al. 2007).

ECM content is increased in all types of hepatic fibrosis. Fibrinogen/fibrin deposits can be detected in the liver immunohistologically after various types of damage. They appear shortly after damage and they persist later in 
fibrotic septa (Neubauer et al. 1995, Luyendyk et al. 2004). Collagen type I is the main component of scars in fibrotic liver. Fibrillar collagen replaces membranelike structures present in normal liver (Pinzani and Gentilini 1999, Brenner et al. 2000). MMPs and their inhibitors participate in the degradation of normal liver ECM. They also may degrade pathological ECM and thus they contribute to the progression or regression of liver fibrosis (Arthur 2000).

The adhesion of cells to the substrate is necessary for the survival of most animal cells. However, the adhesion to the three-dimensional (3D) ECM differs from that observed in classical cell culture on twodimensional substrates such as polystyrene dishes. The involvement of integrins and the function of cells are changed in 3D environment (Cukierman et al. 2001). Cell morphology is also greatly affected by ECM surrounding the cells (Sechler et al. 1998).

Collagen type I may be an important agent influencing the behavior of fibroblastic cells in liver. HSC spread well on polystyrene dishes or on type I collagen coated dishes and show well-developed stress fibres. However, when they are transferred on the gel made of native form of type I collagen, their bodies become slender and they extend long cytoplasmic processes. Cytoskeleton architecture, the distribution of microtubules and actin filaments is altered. mRNA levels of metalloproteinases MMP-2, MT1-MMP and of the tissue inhibitor of metalloproteinases TIMP-2 are increased and zymographic analysis shows the activation of MMP-2 and MMP-9 (Kojima et al. 1998, Wang et al. 2003). HSC embedded in pepsin-solubilized type I collagen gel express high levels of mRNAs of MMP-3, 13 and 14. The expression of collagen I and of urokinase plasminogen activator is downregulated (Takahara et al. 2003).

In contrast to HSC, the behavior of rat liver MFB on collagen or fibrin gels has not yet been studied. In this study, the behavior of MFB on protein gels was compared with that on plastic surface. Morphological differences including cytoskeleton architecture, gene expression on mRNA and protein level and the ability of the cells to modify their environment were examined.

\section{Methods}

Animals

Male Sprague-Dawley rats (Anlab, Prague, Czech Republic) were fed commercial pelleted diet ad libitum and were maintained in an air-conditioned room at $22^{\circ} \mathrm{C}$. They were used at the age of 5 months when they weighed 450$550 \mathrm{~g}$. The experiments were approved by the Ethics Committee of the Faculty of Medicine in Hradec Kralove.

\section{Cell isolation and culture}

Liver was perfused in situ through the portal vein with $\mathrm{Ca}^{2+}$-free Hanks balanced salt solution (Gibco HBSS; Invitrogen, Grand Island, U.S.A.) for $10 \mathrm{~min}$, followed by $100 \mathrm{ml}$ of $0.2 \%$ pronase E (w/v) (Roche, Prague) solution and by $200 \mathrm{ml}$ of $0.01 \%$ collagenase B (Roche). The enzymes were dissolved in complete HBSS and the temperature of the perfusion solution was maintained at $38^{\circ} \mathrm{C}$. The cell suspension was incubated in $0.001 \%$ DNase (Roche) for $30 \mathrm{~min}$. HSC fraction of liver cells was isolated by centrifugation on Optiprep (Axis-Shield, Oslo, Norway) gradient as described before (Jiroutova et al. 2007). The cells were cultured in Dulbecco's modified Eagle medium (DMEM, Sigma, Prague) containing $10 \%$ fetal bovine serum (FBS) (PAA, Cölbe, Germany), $4 \mathrm{mM}$ L-glutamine, $100 \mathrm{U} / \mathrm{ml}$ penicillin, and $100 \mu \mathrm{g} / \mathrm{ml}$ streptomycin (Sigma). Myofibroblasts were obtained after 4 passages of the culture. The numbers of cells used are given in Figures and in Table 1.

\section{Collagen gels}

A modified procedure of Elsdale and Bard (1972) was used to prepare collagen. Rat tail tendons were cut to small pieces, extracted with $0.15 \mathrm{M} \mathrm{NaCl}$ overnight and then with $0.25 \mathrm{M}$ acetic acid for $48 \mathrm{~h}$ with continuous stirring. The suspension was dialyzed against three exchanges of $0.02 \mathrm{M}$ acetic acid and centrifuged at $16,000 \mathrm{~g}$ for $40 \mathrm{~min}$. All these manipulations were done at $4{ }^{\circ} \mathrm{C}$. Collagen concentration was adjusted to $1.33 \mathrm{mg} / \mathrm{ml}$. Filter-sterilized collagen solution was mixed with 4 x DMEM in the ratio $3: 1(\mathrm{v} / \mathrm{v})$ and $1.6 \mathrm{ml}$ aliquots were pipetted immediately into Petri dishes $35 \mathrm{~mm}$ in diameter. The gels were allowed to polymerize in the $\mathrm{CO}_{2}$ incubator for $1 \mathrm{~h}$ at $37^{\circ} \mathrm{C}$ and then they were overlayed with the same volume of DMEM containing $20 \%$ FBS and antibiotics. MFB suspended in the culture medium were pipetted on each gel on the following day and allowed to attach overnight. They were overlayed with another layer of collagen $(0.4 \mathrm{ml})$. The medium on the gels was exchanged daily.

\section{Fibrin gels}

Bovine plasma fibrinogen (Sigma, Prague) was dissolved in phosphate buffered saline (PBS) $\mathrm{pH} 7.41$ at the concentration of $1 \mathrm{mg}$ clottable protein $/ \mathrm{ml}$, sterilized by 
filtration and aliquots of $1.6 \mathrm{ml}$ were pipetted into $35 \mathrm{~mm}$ Petri dishes. Bovine plasma thrombin (Sigma) was added (0.11 U/ml fibrinogen solution). After $1 \mathrm{~h}$ in the $\mathrm{CO}_{2}$ incubator the gels were overlayed with the same volume of 2 x DMEM containing $20 \%$ FBS and left overnight. MFB suspension was pipetted on top. The cells were overlayed with $0.4 \mathrm{ml}$ of fibrin gel on the following day. The medium on the gels was exchanged daily.

\section{Immunocytochemistry}

The cells were fixed in cold acetone after 1 to 7 days in culture. Portions of collagen and fibrin gels were removed from the dishes before fixation. The cells were permeabilized with Triton X-100 and preincubated with $1 \%$ FBS for $1 \mathrm{~h}$. They were stained with a monoclonal antibody against $\alpha$-smooth muscle actin ( $\alpha$-SMA), clone 1A4, (Sigma), dilution 1:400, or with polyclonal rabbit antibodies against MMP-2 and MMP-13 (Santa Cruz Biotechnology, Heidelberg, Germany) diluted 1:100. The incubation was done at $4{ }^{\circ} \mathrm{C}$ for $2 \mathrm{~h}$. The secondary antibody was Cy3-conjugated AffiniPure Donkey AntiRabbit IgG or FITC-conjugated AffiniPure Donkey AntiMouse IgG (Jackson ImmunoResearch Europe, Newmarket, United Kingdom). The slides were mounted in polyvinyl alcohol mounting medium (Sigma) and examined by fluorescence microscopy.

$R N A$ isolation and quantitative reverse transcription polymerase chain reaction ( $q R T-P C R$ )

The cells on plastic were scraped in PBS and dissolved in guanidine thiocyanate containing mercaptoethanol (Jiroutova et al. 2007). The gels were centrifuged at $12,000 \mathrm{~g}$ for 4 minutes and dissolved in saturated guanidine thiocyanate containing mercaptoethanol. Total cellular RNA was extracted according to Chomczynski and Sacchi (1987) and purified using RNeasy Mini Kit (Qiagen, Hilde, Germany). RNA was reverse transcribed using cDNA Reverse Transcription Kit (Applied Biosystems, Prague) and quantified with TaqMan Gene Expression Assays (Applied Biosystems). The results were normalized to $18 \mathrm{~S}$ RNA expression.

\section{Western blot analysis}

The cells were scraped from the plastic, suspended in phosphate buffered saline (PBS) containing $4 \mathrm{mM}$ EDTA and washed 4 fold by this solution. Collagen gel was dissolved by Clostridium histolyticum collagenase Type VII that was chromatographically purified by the producer (Sigma). The cells were washed 4fold with EDTA-containing PBS. The proteins were extracted with cell lysis buffer (Cell Signaling, Danvers, USA). Protein content was determined with bicinchoninic acid (Sigma). Five or $10 \mu \mathrm{g}$ protein were applied on Novex NuPAGE 4-12 \% Bis-Tris gel (Invitrogen Life Technologies, Prague) under nonreducing conditions. The proteins were transferred to $0.2 \mu \mathrm{m}$ Hybond nitrocellulose membrane (GE Healthcare, München, Germany). The antibodies used were rabbit antiMMP-2 (H-76, Santa Cruz), rabbit antiMMP-3 (ab53015, Abcam, Cambridge, United Kingdom), rabbit antiMMP-9 (H-129, Santa Cruz), rabbit antiMMP-13 (H-230, Santa Cruz), mouse anti $\alpha$-SMA (1A4, Sigma), mouse anti $\beta$-actin (AC74, Sigma), mouse antiGAPDH (6C5, Abcam) and rabbit anticytochrome c (ab18817, Abcam). The membranes were incubated with the antibodies at $4{ }^{\circ} \mathrm{C}$ overnight. The secondary antibodies were from Santa Cruz. Detection was done with Western Blotting Luminol Reagent (Santa Cruz).

\section{Zymography}

Zymographic analysis was performed on conditioned media. The cells cultured on gels were released with trypsin and plated on plastic for $16 \mathrm{~h}$. The medium was collected and compared with the medium of trypsinized cells cultured previously on plastic. Protein concentration in the media was adjusted to $1 \mathrm{mg} / \mathrm{ml}$. Ten microliter aliquots were electrophoresed in $8 \%$ SDSpolyacrylamide gel containing $0.1 \%$ gelatin. The gel was washed in $2.5 \%$ Triton $\mathrm{X}-100$ for $1 \mathrm{~h}$ and subsequently incubated for $15 \mathrm{~h}$ at $37^{\circ} \mathrm{C}$ in $50 \mathrm{mmol} / 1$ Tris- $\mathrm{HCl}$ buffer $\mathrm{pH} 7.4$ containing $15 \mathrm{mmol} / \mathrm{l}$ sodium chloride and $10 \mathrm{mmol} / \mathrm{l}$ calcium chloride. The gel was stained with Coomasie brillant blue and destained.

\section{Gel digestion}

Petri dishes, $35 \mathrm{~mm}$ in diameter, were preweighed. MFB were plated on fibrin or on collagen gel. Control dishes were incubated without cells. After 5 days of incubation, the dishes were washed with PBS, dried at $80{ }^{\circ} \mathrm{C}$ and weighed. In some experiments, CL-82198 (Sigma), selective inhibitor of MMP-13 (Chen et al. 2000), was added to the medium to make the final concentration of the inhibitor $10 \mu \mathrm{M}$.

\section{Statistical analysis}

One sample t-test or Wilcoxon-Signed-Rank test was used to evaluate statistical significance of the results. The significance level was $\mathrm{p}=0.05$. 


\section{Results}

\section{The influence of collagen gel}

\section{a) Cell morphology and cytoskeleton}

MFB cultured on plastic substrates under standard conditions were spread with prominent stress fibers staining for alpha-smooth muscle actin ( $\alpha$-SMA)
(Fig. 1a, 2a). MFB growing on fibrin gel were smaller in size than the cells on plastic, they were elongated with long processes and contained visible stress fibers closer to one another (Fig. 1b). They were distributed all over the gel (Fig. 2b). The cells on collagen gel were small but still staining for actin. They extended short processes (Fig. 1c) and had a tendency to aggregate into star-shaped clusters (Fig. 2c).
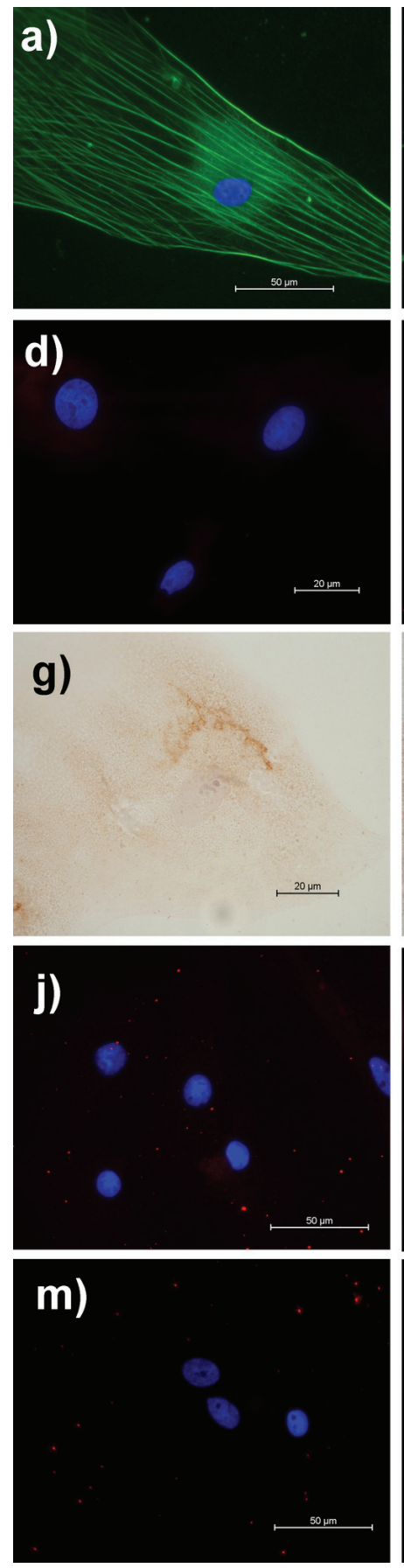
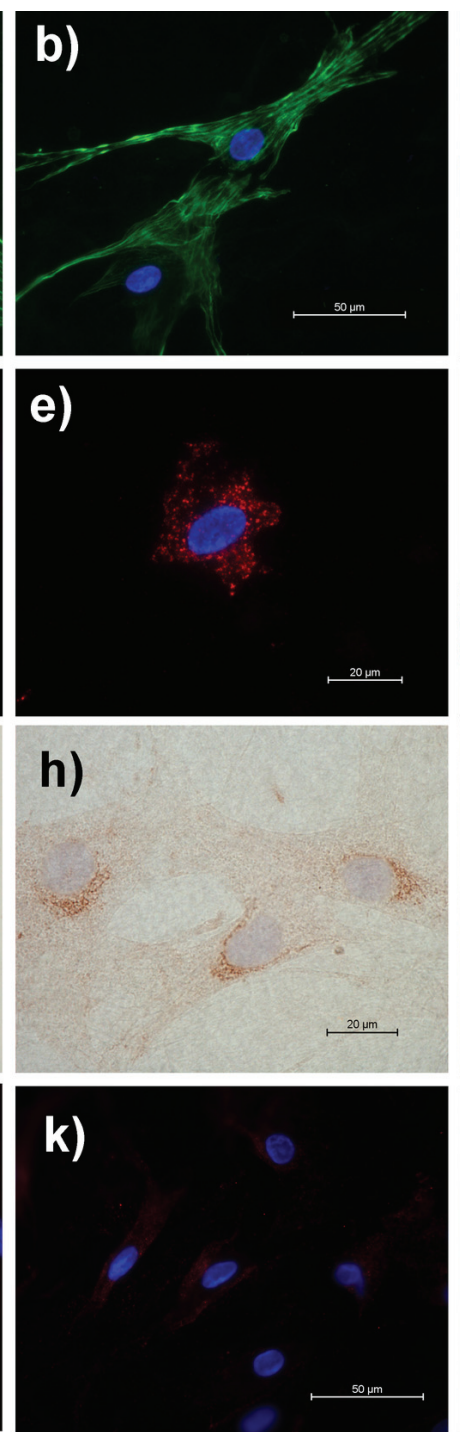

\section{n)}

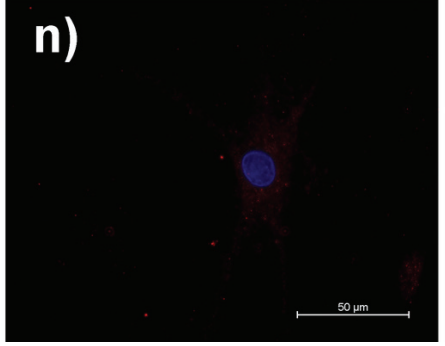

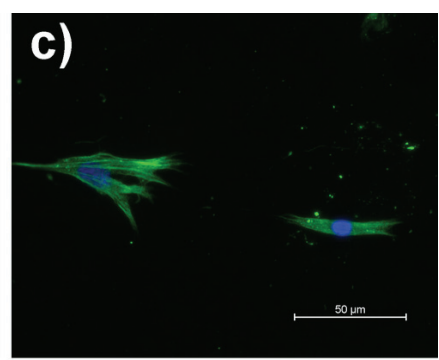

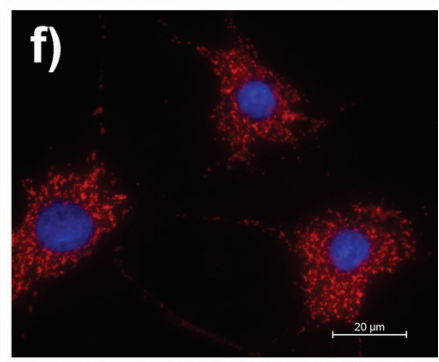

i)
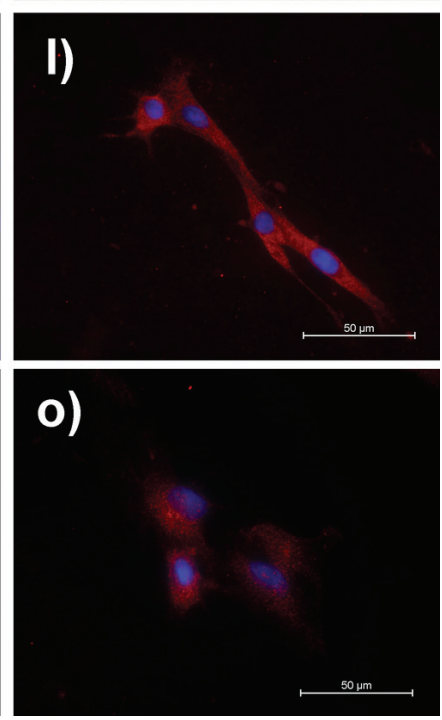

Fig. 1. Immunocytochemistry of MFB. MFB were cultured for 5 days on plastic $(\mathbf{a}, \mathbf{d}, \mathbf{g}, \mathbf{j}, \mathbf{m})$, on fibrin gel $(\mathbf{b}, \mathbf{e}, \mathbf{h}, \mathbf{k}, \mathbf{n})$ or on type I collagen gel $(\mathbf{c}, \mathbf{f}, \mathbf{i}, \mathbf{l}, \mathbf{o})$. They were stained with antibodies against a-SMA $(a, b, c)$, MMP-2 (d, e, f), MMP-3 $(g, h, i)$, MMP-9 (j, k, l) and MMP-13 $(m, n, o)$. The antigens were visualized by immunoflurescence or by peroxidase reaction (MMP-3). Cell numbers were 0.05 million/per $35 \mathrm{~mm}$ Petri dish. 

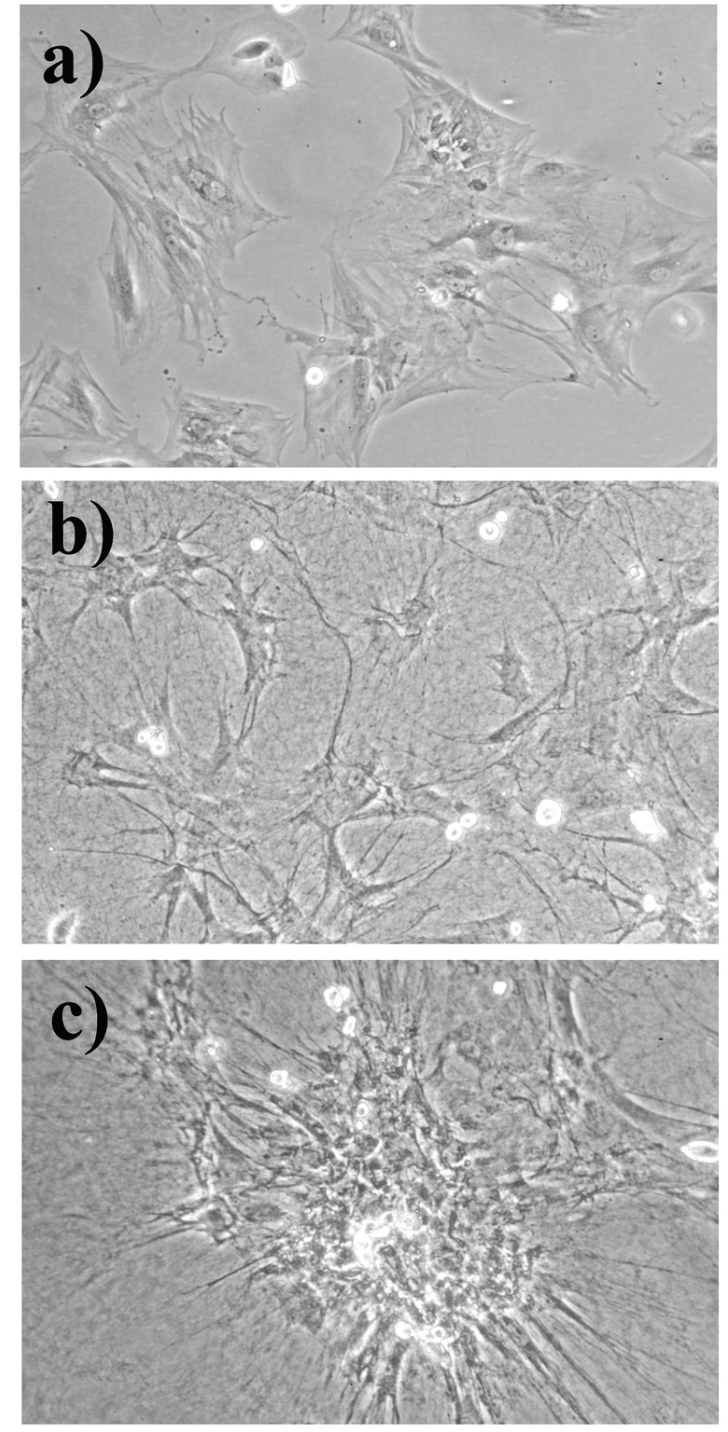

Fig. 2. MFB in phase contrast. MFB $24 \mathrm{~h}$ after plating on plastic (a), on fibrin gel (b) or on type I collagen gel (c). Cell numbers were 0.8 million $/ 100 \mathrm{~mm}$ Petri dish, 0.25 million $/ 35 \mathrm{~mm}$ Petri dish.

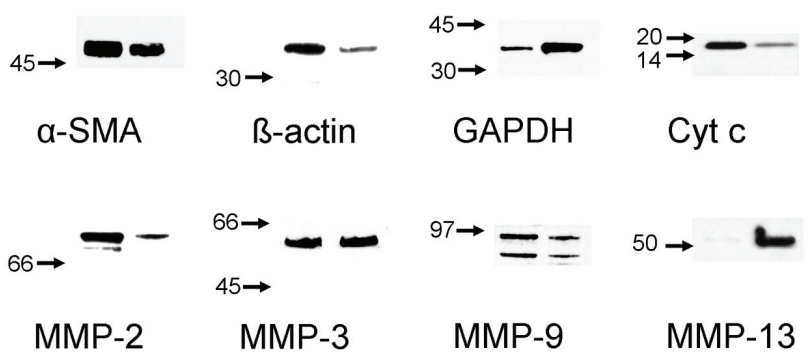

Fig. 3. The lysates of cells cultured on plastic substrate (left lanes) or on collagen gel (right lanes) were subjected to Western blotting under non-reducing conditions. Molecular weights in $\mathrm{kDa}$ are indicated. GAPDH - glyceraldehyde-3-phosphate dehydrogenase, cyt c - cytochrome c.

The changes in cell morphology and in the cytoskeleton shown in Figures 1 and 2 were reflected in the changes of cytoskeleton proteins determined by Western blotting (Fig. 3); $\alpha$-SMA and $\beta$-actin levels were lower in the cells cultured on collagen, the decrease in $\beta$ actin was much more pronounced.

\section{b) Collagen gel degradation and expression of} metalloproteinases

When MFB were cultured on collagen gels for 1 week, they solubilized $51 \%$ of the substrate, while only $15 \%$ of fibrin gel was degraded (Fig. 4). mRNA of MMP-13, rat collagenase, was hardly detectable when MFB were cultured on a plastic substrate but it increased more than fortyfold when the cells were transferred on collagen gel (Table 1). Similar increase was observed in Western blots (Fig. 3). MMP-13 was also detected in MFB on collagen by immunocytochemistry. When CL82198, a selective MMP-13 inhibitor, was added to the culture medium at $10 \mu \mathrm{M}$, the dissolved portion of the gel was only by $11 \%$ smaller (not shown). Participation of other MMPs in collagen breakdown could thus be expected.

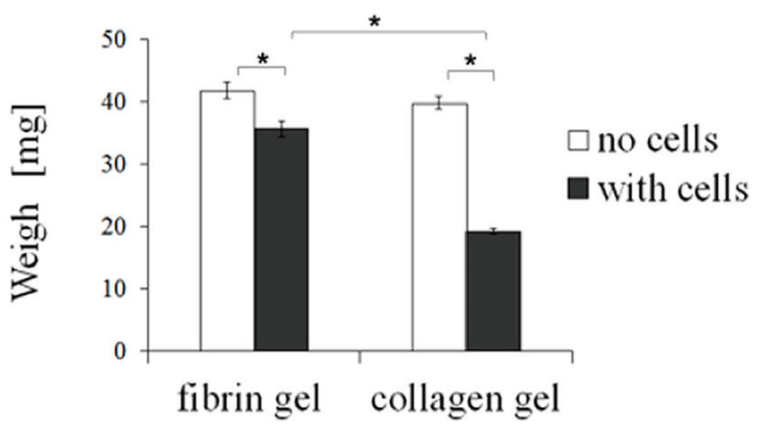

Fig. 4. Fibrin and collagen gel digestion by MFB. Petri dishes were preweighed. MFB ( 0.25 million cells) were plated on fibrin or on collagen gel. Five days after plating the dishes were washed with PBS and dried at $80^{\circ} \mathrm{C}$. The weights of the dried gels are shown. Means \pm S.E.M. $(n=8)$ are given. Asterisks denote statistically significant results $(p<0.05)$.

After initial splitting of collagen molecule by collagenase, the breakdown of native collagen may be completed by gelatinases and other metalloproteinases. MMP-2 and -9 mRNAs showed a mild increase in MFB on collagen (Table 1). Protein levels of MMP-2 and MMP-9 (gelatinases A and B, respectively) were lower in the cells cultured on the gel when compared to MFB on plastic (Fig. 3). The bands corresponding to the proforms and activated forms of gelatinases were detected. Zymographic analysis of cell conditioned media showed greater activity of both gelatinases in gelatin breakdown (Fig. 5). Both gelatinases were detected by 
immunocytochemistry in MFB cultured on collagen (Fig. 1f, 1). Discernible foci of MMP-2 were observed in MFB suggesting formation of secretory granules. However, all immunocytochemistry results may be affected by changes in cell size and shape when flat cells, well spread on plastic surface, assume a 3D shape in 3D space. Fluorescence intensity is low when fluorescent particles are spread over large surface. MMP-3 mRNA was also stimulated but the variability of the stimulation was high and the result was not statistically significant (Table 1). No difference was found when MMP-3 contents in cells on plastic and on collagen were compared by Western analysis (Fig. 4). The expression of membrane-bound MMP-14 (MT1-MMP) mRNA was increased threefold (Table 1).

Table 1. Expression of selected genes in MFB cultured on fibrin or on type I collagen gel analyzed by qRT-PCR.

\begin{tabular}{|c|c|c|c|c|}
\hline & $\begin{array}{c}\text { Gene abbreviation } \\
\text { Gene name }\end{array}$ & $\begin{array}{l}\text { Accession } \\
\text { number }\end{array}$ & Fibrin gel & Collagen gel \\
\hline \multirow{9}{*}{$\begin{array}{l}\text { Metalloproteinases } \\
\text { and inhibitors }\end{array}$} & $\begin{array}{c}\text { MMP-2 } \\
\text { Gelatinase A }\end{array}$ & NM_031054 & $92 \pm 21$ & $167 \pm 11^{\mathrm{a}, \mathrm{b}}$ \\
\hline & $\begin{array}{c}\text { MMP-3 } \\
\text { Stromelysin-1 }\end{array}$ & NM_133523 & $579 \pm 271$ & $1772 \pm 1333$ \\
\hline & $\begin{array}{c}\text { MMP-7 } \\
\text { Matrilysin }\end{array}$ & NM_012864 & $51 \pm 17^{\mathrm{a}}$ & $87 \pm 23$ \\
\hline & $\begin{array}{c}\text { MMP-9 } \\
\text { Gelatinase B }\end{array}$ & NM_031055 & $20 \pm 3^{a}$ & $162 \pm 65^{b}$ \\
\hline & $\begin{array}{c}\text { MMP-13 } \\
\text { Collagenase-3 }\end{array}$ & XM_343345 & $105 \pm 49$ & $4086 \pm 3289^{\mathrm{a}, \mathrm{b}}$ \\
\hline & $\begin{array}{c}\text { MMP-14 } \\
\text { Membrane-inserted MMP }\end{array}$ & NM_031056 & $80 \pm 12$ & $298 \pm 41^{\mathrm{a}, \mathrm{b}}$ \\
\hline & $\begin{array}{c}\text { TIMP-1 } \\
\text { Metallopeptidase inhibitor } 1\end{array}$ & NM_053819 & $95 \pm 10$ & $84 \pm 19$ \\
\hline & $\begin{array}{c}\text { TIMP-2 } \\
\text { Metallopeptidase inhibitor } 2\end{array}$ & NM_021989 & $86 \pm 17$ & $128 \pm 16$ \\
\hline & $\begin{array}{c}\text { PAI-1 } \\
\text { Serine peptidase inhibitor } 1\end{array}$ & NM_012620 & $67 \pm 10^{a}$ & $30 \pm 5^{\mathrm{a}, \mathrm{b}}$ \\
\hline \multirow{4}{*}{ ECM components } & $\begin{array}{c}\text { COLla2 } \\
\text { Procollagen type I, alpha } 2\end{array}$ & NM_053356 & $149 \pm 35$ & $106 \pm 11$ \\
\hline & $\begin{array}{c}\text { COL } 4 a 1 \\
\text { Procollagen type IV, alpha } 1\end{array}$ & XM_214400 & $101 \pm 14$ & $93 \pm 21$ \\
\hline & $\begin{array}{c}\text { COL12a1 } \\
\text { Procollagen type XII, alpha } 1\end{array}$ & XM_243912 & $105 \pm 11$ & $54 \pm 5^{\mathrm{a}, \mathrm{b}}$ \\
\hline & $\begin{array}{c}\text { TSP-2 } \\
\text { Thrombospondin } 2\end{array}$ & XM_214778 & $97 \pm 13$ & $44 \pm 6^{\mathrm{a}, \mathrm{b}}$ \\
\hline \multirow{6}{*}{ Cytokines } & $I L-6$ & NM_012589 & $98 \pm 23$ & $49 \pm 16^{\mathrm{a}}$ \\
\hline & TGF betal & NM_021578 & $90 \pm 13$ & $195 \pm 28^{\mathrm{a}, \mathrm{b}}$ \\
\hline & TGF beta2 & NM_031131 & $72 \pm 5$ & $22 \pm 2^{\mathrm{a}}$ \\
\hline & TGF beta 3 & NM_013174 & $53 \pm 5^{\mathrm{a}}$ & $22 \pm 5^{\mathrm{a}, \mathrm{b}}$ \\
\hline & $C T G F$ & NM_022266 & $92 \pm 16$ & $40 \pm 3^{\mathrm{a}, \mathrm{b}}$ \\
\hline & $\begin{array}{c}\text { SPP1 } \\
\text { Osteopontin }\end{array}$ & NM_012881 & $55 \pm 8^{a}$ & $217 \pm 51^{b}$ \\
\hline
\end{tabular}

MFB were cultured on the gels for 5 days. The results are shown as percentage of the expression on plastic. Cell numbers were $0.8 \mathrm{million} / 100 \mathrm{~mm}$ Petri dish, 0.25 million/on fibrin gel or on collagen gel in $35 \mathrm{~mm}$ Petri dish. Statistical significance is indicated $(p<0.05) .{ }^{a}$ fibrin or collagen vs. plastic, ${ }^{b}$ collagen vs. fibrin. 


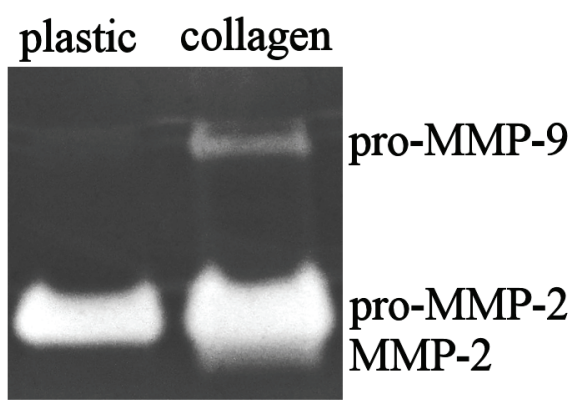

Fig. 5. Zymography of conditioned media. Trypsinized MFB were plated on plastic or tranferred from collagen to plastic.

\section{c) Regulatory proteins and cytokines}

Changes in the energetic metabolism are suggested by altered protein expression of glyceraldehyde-3-phosphate dehydrogenase (GAPDH), the key enzyme of glycolysis, and cytochrome c, the enzyme of mitochondrial respiratory chain. While GAPDH protein content in MFB cultured on collagen was higher, cytochrome c protein content in MFB lysate decreased after transfer of MFB on collagen (Fig. 3).

The expression of various agents that may regulate MMPs synthesis and activity was studied on mRNA level (Table 1). The expression of collagenase substrates, collagen types I and XII, did not change or decreased, respectively. The expression of the gelatinase substrate, collagen type IV, did not change.

The expression of specific tissue inhibitors of MMPs (TIMP-1 and -2) did not change after transferring MFB on collagen gel. Plasminogen activator inhibitor (PAI-1) mRNA level decreased to one third. Osteopontin (secreted phosphoprotein 1) and thrombospondin-2 are ECM components that may be involved in the regulation of MMPs expression and activity. Osteopontin may function as a cytokine. The expression of osteopontin increased twofold, while that of thrombospondin 2 decreased to about one half.

Significant shifts in the expression of cytokines of TGF- $\beta$ family were found in MFB cultured on collagen gels. TGF- $\beta 1$ expression increased about twofold while that of TGF- $\beta 2$ and TGF- $\beta 3$ dropped to less than one quarter. Connective tissue growth factor (CTGF) and interleukin-6 (IL-6) expression decreased to about one half of the values found on plastic.

\section{The influence of fibrin gel}

The shape and size of MFB growing on fibrin gel differed greatly from the cells cultured on plastic (Fig. 1a,b). The expression of MMPs detected by immunocytochemistry in MFB on fibrin was not much different from the cells on plastic (Fig. 1d, e, g, h, j, k, $\mathrm{m}, \mathrm{n})$.

Little difference was also found in MMPs mRNA expression (Table 1). MMP-3 mRNA level was insignificantly increased. On the other hand, MMP-7 and MMP-9 expression was decreased substantially and significantly. Other MMPs did not change.

Little change was found in the ECM proteins group, with the exception of osteopontin. The ratio between the members of TGF- $\beta$ family changed but not so dramatically as in the MFB cultured on collagen, IL-6 and CTGF expression did not change at all.

\section{Discussion}

Cells cultured in vitro respond both to chemical composition and mechanical stiffness of the substrate. Biochemical and mechanical stimuli lead to changes in cell phenotype and to subsequent remodelling of the matrix (Stegemann et al. 2005). Cell cytoskeleton plays an important role in the transmission of the ECM signals (Unemori and Werb 1986).

The influence of ECM proteins fibrin and collagen on liver MFB has not been studied before. MFB were isolated from the fraction of nonparenchymal liver cells by repeated passaging and plated on fibrin or collagen gel in this study. The cells were covered with a layer of the respective protein after they adhered to the substrate. This technique allows fibroblastic cells to migrate (Haas et al. 2001). MFB cultured on polystyrene dishes were large and spread, possibly in an effort to endocytose the dish. After they were transferred on collagen gel they decreased in size and turned slender with short processes. They resembled myofibroblastic cells isolated from human liver, passaged five to tenfold and transferred on type I collagen gel (Li et al. 1999). Rat HSC respond in a similar way but their processes are longer (Kojima et al. 1998). MFB formed clusters on collagen in a similar way as HSC (Senoo et al. 1996).

$\alpha$-SMA expression is a characteristic feature of rat and human myofibroblastic cells (Kojima et al. 1998, Li et al. 1999). As shown in our study, prolonged cultivation of MFB on collagen decreased the expression of both $\alpha$-SMA and $\beta$-actin. Actin isoforms perform distinct functions in the cells, $\alpha$-actin is responsible for contractile activity of the cells, $\beta$-actin is involved in cell spreading (Khaitlina 2007). Our results support the theory that the expression of $\alpha$-SMA is greatly influenced by the 
rigidity of the substrate; it is higher on collagen-coated plastic than on collagen-coated polyacrylamide gel as shown in human trabecular cells (Schlunck et al. 2008). The composition of the matrix is also important. Plating human dermal fibroblasts on collagen inhibits $\alpha$-SMA synthesis (Ehrlich et al. 2006), which corresponds with our findings in MFB. The expression of $\beta$-actin in rat hepatocytes depends on the composition of surrounding ECM (Otsu et al. 2001).

Also the energy metabolism of MFBs may have been changed as suggested by the relative increase in GAPDH protein a decrease in cytochrome c. Glycolytic enzymes are attached to fibrillar actin and fibril rearrangement is accompanied by the activation of glycolysis (Bereiter-Hahn et al. 1995). Besides that, collagen matrix is likely to decrease the diffusion of oxygen while its consumption by proliferating cells increases. HepG2 cells cultured in collagen scaffold respond to this disproportion by increased expression of enzymes involved in glycolysis and decreased expression of mitochondrial proteins (Pruksakorn et al. 2010).

The reorganization of actin cytoskeleton or the change in cell shape may be associated with the induction of collagenase in rabbit synovial fibroblasts (Unemori et al. 1986, Kheradmad et al. 1998). To evaluate the contribution of collagenase to the observed degradation of collagen gel we used collagenase inhibitor CL-82198. This inhibitor inhibits $89 \%$ collagenase activity when used at $10 \mu \mathrm{M}$ concentration (Chen et al. 2000). However, it decreased the amount of collagen dissolved by MFB only by $11 \%$. The degradation of collagen gel that occurred seemed to require a joint action of a few proteinases.

The transfer of liver MFB on collagen induced an increase in the expression of mRNA of a group of proteinases, although to different degrees. The results of zymography suggested that MMP-2 and MMP-9 participated in gel degradation. Protein content of MMP2 and MMP-9 was decreased in MFB on collagen as indicated by Western analysis. The MMPs may be secreted into the medium.

MMPs are synthesized as proenzymes. Plasminogen/plasmin system is involved in the activation of some MMPs (Lijnen 2000). The decrease in the expression of plasminogen activator inhibitor PAI-I mRNA that we observed in MFB on collagen gel may result in greater activity of plasmin and greater MMPs activation. The expression of specific MMPs inhibitors, TIMPs, did not change. ECM glycoprotein thrombospondin-2, whose expression was decreased, is known to bind MMP-2 and to inhibit its activity (Yang et al. 2000).

Collagen gel had little effect on the expression of MMPs substrates, fibrillar collagen I and net-forming collagen IV. The expression of collagen XII, a representative of the FACIT group of collagens, was decreased to about one half.

TGF- $\beta 1$ is known to stimulate ECM production and to inhibit cell proliferation in liver and in other tissues (Gressner et al. 2002). It modulates the expression of collagen I and collagenase MMP-13 mRNA expression in HSC in a reciprocal manner (Lechuga et al. 2004). In contrast, TGF- $\beta 2$ attenuates fibrosis in some animal models (Hill et al. 2001). TGF- $\beta 3$ is expressed in cutaneous wounds; it is differently regulated than TGF$\beta 1$ and TGF- $\beta 2$ and reduces scarring (Frank et al. 1996). In our study, the transfer of MFB on collagen gel caused shifts in the expression of TGF- $\beta$ isoforms, namely, the ratio of TGF- $\beta 1$ to TGF- $\beta 2$ or TGF- $\beta 3$. The relationship of these changes to the modification of the expression of ECM components is not clear. Moreover, it was shown in fibroblasts that collagen lattice may modulate the effect of TGF- $\beta$ on cells (Coustry et al. 1990).

CTGF, a member of CCN gene family, is overexpressed in fibrotic liver as well as in HSC. In some cells, e.g. in hepatocytes, but not in HSC, its expression is induced by TGF- $\beta 1$ (Gressner et al. 2007). CTGF expression decreased in MFB on collagen gel.

IL-6 is a cytokine that stimulates collagen synthesis in vivo and reduces MMP-2 expression (Choi et al. 1994, Bansal et al. 2005). Its expression in MFB on collagen was decreased. In contrast, the expression of osteopontin, a cytokine inducing MMP-9 activation and cell migration (Rangaswami et al. 2004), was increased.

MFB are thought to participate in the healing of damaged liver and in fibrogenesis. HSC almost exclusively respond to acute liver injury and both HSC and MFB are involved in scar formation in chronically injured liver (Knittel et al. 1999a). HSC migration plays an important role in the formation of liver fibrotic septa (Carloni et al. 1997). Migrating cells utilize both proteolytic activities of MMPs and non-proteolytic mechanisms. The propeller-like domains in their molecules may facilitate cellular movement (Even-Ram and Yamada 2005, Dufour et al. 2008).

Interleukin-1 induces expression and secretion of MMPs in HSC embedded in 3D collagen I matrix. MMP9 is converted to its active form when HSC are in type I 
collagen and is responsible for the activation of HSC. Collagen is degraded (Han et al. 2004).

This study shows that MFB have a substantial ability to degrade collagen type I, the essential component of the ECM in fibrotic liver, without stimulation by cytokines. The cell shape that MFB acquire on collagen gel is compatible with migratory phenotype. MFB may be able to migrate under in vivo conditions although collagenous matrix in liver may be more difficult to overcome because of collagen crosslinking that was not present in this ECM model. The influence of collagen gel on MFB is rather specific as the changes caused by fibrin gel were much less prominent and sometimes in opposite direction. The increased expression and activity of a group of MMPs is accompanied with changes in cytoskeleton and with significant shifts in the expression of a number of profibrotic cytokines.

\section{Conflict of Interest}

The authors declare no conflict of interest.

\section{Acknowledgements}

The authors wish to thank to Dr. E. Cermakova for the statistical evaluation of the results. Technical help of Ms M. Hajzlerova and of Ms P. Kazimirova is greatfully acknowledged. This work was supported by grants from the Grant Agency of Charles University No. 86/2006/C/LFHK and No. 699912 and by the project PRVOUK P37/01.

\section{References}

ARTHUR MJP: Fibrogenesis II. Metalloproteinases and their inhibitors in liver fibrosis. Am J Physiol 279: G245-G249, 2000.

BANSAL MB, KOVALOVICH K, GUPTA R, LI W, AGARWAL A, RADBILL B, ALVAREZ CE, SAFADI R, FIEL MI, FRIEDMAN SL, TAUB RA: Interleukin-6 protects hepatocytes from $\mathrm{CCl}_{4}$-mediated necrosis and apoptosis in mice by reducing MMP-2 expression. J Hepatol 42: 548-556, 2005.

BEREITER-HAHN J, STÜBIG C, HEYMAN V: Cell cycle-related changes in F-actin distribution are correlated with glycolytic activity. Exp Cell Res 218: 551-560, 1995.

BRENNER DA, WATERBOER T, CHOI SK, LINDQUIST JN, STEFANOVIC B. BURCHARDT E, YAMAUCHI M, GILLAN A, RIPPE RA: New aspects of hepatic fibrosis. $J$ Hepatol 32 (Suppl 1): 32-38, 2000.

CARLONI V, ROMANELLI RG, PINZANI M., LAFFI G, GENTOLINI P: Focal adhesion kinase and phospolipase $\mathrm{C} \gamma$ involvement in adhesion and migration of human hepatic stellate cell. Gastroenterology 112: 522-531, 1997.

CHEN JM, NELSON FC, LEVIN JI, MOBILIO D, MOY FJ, NILAKANTAN R, ZASK A, POWERS R: Structurebased design of a novel, potent, and selective inhibitor for MMP-13 utilizing NMR spectroscopy and computer-aided molecular design. J Am Chem Soc 122: 9648-9654, 2000.

CHOI I, KANG H-S, YANG Y, PYUN K-H: IL-6 induces hepatic inflammation and collagen synthesis in vivo. Clin Exp Immunol 95: 530-535, 1994.

CHOMCZYNSKI P, SACCHI N: Single-step method of RNA isolation by acid guanidinium thiocyanate-phenolchloroform extraction. Anal Biochem 162: 156-159, 1987.

COUSTRY F, GILLERY P, MAQURT F-X, BOREL J-P: Effect of transforming growth factor $\beta$ on fibroblasts in three-dimensional lattice cultures. FEBS Lett 262: 339-341, 1990.

CUKIERMAN E, PANKOV R, STEVENS DR, YAMADA KM: Taking cell-matrix adhesions to the third dimension. Science 294: 1708-1712, 2001.

DUFOUR A, SAMPSON NS, ZUCKER S, CAO J: Role of the hemopexin domain of matrix metalloproteinases in cell migration. J Cell Physiol 217: 643-651 2008.

EHRLICH HP, ALLISON GM, LEGGETT M: The myofibroblast, cadherin, $\alpha$ smooth muscle action and the collagen effect. Cell Biochem Funct 24: 63-70, 2006.

ELSDALE T, BARD J: Collagen substrata for studies on cell behavior. J Cell Biol 54: 626-637, 1972.

EVEN-RAM S, Yamada KM: Cell migration in 3D matrix. Curr Opin Cell Biol 17: 524-532, 2005.

FRANK S, MADLENER M, WERNER S: Transforming growth factors $\beta 1, \beta 2$, and $\beta 3$ and their receptors are differentially regulated during normal and impaired wound healing. J Biol Chem 271: 10188-10193, 1996. 
GRESSNER AM, WEISKIRCHEN R, BREITKOPFE K, DOOLEY S: Roles of TGF-beta in hepatic fibrosis. Front Biosci 7: 793-807, 2002.

GRESSNER OA, LAHME B, DEMIRCI I., GRESSNER AM, WEISKIRCHEN R: Differential effects of TGF- $\beta$ on connective tissue growth factor $(\mathrm{CTGF} / \mathrm{CCN} 2)$ expression in hepatic stellate cells and hepatocytes. $J$ Hepatol 47: 699-710, 2007.

GUYOT C, LEPREUX S, COMBE C. DOUDNIKOFF E, BIOULAC-SAGE P, BALABAUD C, DESMOULIERE A: Hepatic fibrosis and cirrhosis: the (myo)fibroblastic cell subpopulations involved. Int J Biochem Cell Biol 38: 135-151, 2006.

HAAS VR, SANTOS AR Jr, WADA MLF: Behaviour of fibroblastic cells cultured in collagen I using the sandwich technique. Cytobios 106: 255-267, 2001.

HAN Y-P, ZHOU L, WANG J, XIONG S, GARNER WL, FRENCH SW, TSUKAMOTO H: Essential role of matrix metaloproteinases in interleukin-1-induced myofibroblastic activation of hepatic stellate cell in collagen. $J$ Biol Chem 279: 4820-4828, 2004.

HILL C, FLYVBJERG A, RASCH R, BAK M, LOGAN A: Transforming growth factor- $\beta 2$ antibody attenuates fibrosis in the experimental diabetic rat kidney. J Endocrinol 170: 647-651, 2001.

JIROUTOVA A, SLAVKOVSKY R, CERMAKOVA M., MAJDIAKOVA L., HANOVCOVA I, BOLEHOVSKA R, HAJZLEROVA M, RADILOVA H, RUSZOVA E, KANTA J: Expression of mRNAs related to connective tissue metabolism in rat hepatic stellate cells and myofibroblasts. Exp Toxicol Pathol 58: 263-273, 2007.

KHAITLINA SY: Mechanisms of spatial segregation of actin isoforms. Cell Tissue Biol 1: 293-304, 2007.

KHERADMAD F, WERNER E, TREMBLE P, SYMONS M, WERB Z: Role of Rac1 and oxygen radicals in collagenase-1 expression induced by cell shape change. Science 280: 898-902, 1998.

KINNMAN N, HOUSSET C: Peribiliary myofibroblasts in biliary type liver fibrosis. Front Biosci 7: d496-d503, 2002.

KNITTEL T, KOBOLD D, PISCAGLIA F, SAILE B, NEUBAUER K., MEHDE M, TIMPL R, RAMADORI G: Localization of liver myofibroblasts and hepatic stellate cells in normal and diseased rat livers: distinct roles of (myo-)fibroblast subpopulations in hepatic tissue repair. Histochem Cell Biol 112: 387-401, 1999a.

KNITTEL T, KOBOLD D, SAILE B, GRUNDMANN A, NEUBAUER K, PISCAGLIA F, RAMADORI G: Rat liver myofibroblasts and hepatic stellate cells: different cell populations of the fibroblast lineage with fibrogenic potential. Gastroenterology 117: 1205-1221, 1999b.

KOJIMA N, SATO M, IMAI K, MIURA M, MATANO Y, SENOO H: Hepatic stellate cells (vitamin A-storing cells) change their cytoskeleton structure by extracellular matrix components through a signal transduction system. Histochem Cell Biol 110: 121-128, 1998.

LECHUGA CG, HERNANDEZ-NAZARA ZH, DOMINGUEZ ROSALES J-A, MORRIS ER, RINCON AR, RIVASESTILLA AM, ESTEBAN-GAMBOA A, ROJKIND M: TGF- $\beta 1$ modulates matrix metallorpoteinase-13 expression in hepatic stellate cells by complex mechanisms involving p3MAPK, PI3-kinase, AKT, and p70S6K. Am J Physiol 287: G974-G987, 2004.

LI Y-L, SATO M, KOJIMA N, MIURA M, SENOO H: Regulatory role of extracellular matrix components in expression of matrix metalloproteinases in cultured hepatic stellate cells. Cell Struct Funct 24: 255-261, 1999.

LIJNEN HR: Molecular interactions between the plasminogen/plasmin and matrix metalloproteinase systems. Fibrinolysis Proteolysis 14: 175-181, 2000.

LUYENDYK JP, MADDOX JF, GREEN CD, GANEY PE, ROTH RA: Role of hepatic fibrin idiosyncrasy-like liver injury from lipopolysaccharide-ranitidine coexposure in rats. Hepatology 40: 1342-1351, 2004.

NEUBAUER K, KNITTEL T, ARMBRUST T, RAMADORI G: Accumulation and cellular localization of fibrinogen/fibrin during short-term and long-term rat liver injury. Gastroenterology 108: 1124-1135, 1995.

OGAWA T, TATENO C, ASAHINA K, FUJII H, KAWADA N, OBARA M, YOSHIZATO K: Identification of vitamin A-free cells in a stellate cell-enriched fraction of normal rat liver a myofibroblasts. Histochem Cell Biol 127: 161-174, 2007.

OTSU K, ITO K, KUZUMAKI T, IUCHI Y: Differential regulation of liver-specific and ubiquitously-expressed genes in primary rat hepatocytes by the extracellular matrix. Cell Physiol Biochem 11: 33-40, 2001.

PAROLA M, MARRA F, PINZANI M: Myofibroblast-like cells and liver fibrogenesis: emerging concepts in a rapidly moving scenario. Mol Aspects Med 29: 58-66, 2008. 
PINZANI M., GENTILINI P: Biology of hepatic stellate cells and their possible relevance in the pathogenesis of portal hypertension in cirrhosis. Semin Liver Dis 19: 397-410, 1999.

PRUKSAKORN D, LIRDPRAPAMONGKOL K, CHOKCHAICHAMNANKIT D, SUBHASITANONT P, CHIABLAEM K, SVASTI J, SRISOMSAP C: Metabolic alteration of HepG2 in scaffold-based 3-D culture: proteomic approach. Proteomics 10: 3896-3904. 2010.

RANGASWAMI H, BULBULE A, KUNDU GC: Nuclear factor-inducing kinase plays a crucial role osteopontininduced MAPK/IKB-mediated promatrix metalloproteinase-9 activation. J Biol Chem 279: 38921-38935, 2004.

SCHLUNCK G, HAN H, WECKER T, KAMPIK, D, MEYER-TER-VEHN T, GREHN F: Substrate rigidity modulates cell-matrix interactions and protein expression in human trabecular meshwork cells. Invest. Ophthalmol Vis Sci 49: 262-269, 2008.

SECHLER JL, CORBETT SA, WENK MB, SCHWARZBAUER JE: Modulation of cell-extracellular matrix interactions. Ann NY Acad Sci 857: 143-154, 1998.

SENOO H, IMAI K, SATO M, KOJIMA N, MIURA M, HATA R-I: Three-dimensional structure of extracellular matrix reversibly regulates morphology, proliferation and collagen metabolism of perisinusoidal stellate cells (vitamin A-storing cells). Cell Biol Int 20: 501-512, 1996.

STEGEMANN JP, HONG H, NEREM RM: Mechanical, biochemical, and extracellular matrix effects on vascular smooth muscle cell phenotype. $J$ Appl Physiol 98: 2321-2327, 2005.

TAKAHARA T, ZHANG LP, YATA Y, XUE F, MINEMURA M, SATO H, WATANABE A: Modulation of matrix metalloproteinase-9 in hepatic stellate cells by three-dimensional type I collagen: its activation and signaling pathway. Hepatol Res 26: 318-326, 2003.

UNEMORI EN, WERB Z: Reorganization of polymerized actin: a possible trigger for induction of procollagenase in fibroblasts cultured in and on collagen gels. J Cell Biol 103: 1021-1031, 1986.

WANG DR, SATO M, LI LN, MIURA M, KOJIMA N, SENOO H: Stimulation of pro-MMP-2 production and activation by native form of extracellular type I collagen in cultured hepatic stellate cells. Cell Struct Funct 28: 505-513, 2003.

YANG Z, KYRIAKIDES TR, BORNSTEIN P: Matricellular proteins as modulators of cell-matrix interactions: adhesive defect in thrombospondin 2-null fibroblasts is a consequence of increased levels of matrix metaloproteinase-2. Mol Biol Cell 11: 3353-3364, 2000. 